\title{
Managing Power Sharing of the State on Islamic Modern Society: a Case Study of Indonesia
}

\author{
Ibnu Sina Chandranegara ${ }^{1}$, Rantawan Djanim ${ }^{1}$, Budi Astuti ${ }^{1}$ \\ ${ }^{1}$ Faculty of Law University of Muhammadiyah Jakarta, Jalan K.H. Ahmad Dahlan, Cireundeu, Ciputat, \\ Tangerang, Banten
}

Author for correspondence/E-mail: ibnusinach@gmail.com

\begin{abstract}
On reasearch "checks and balances" in legal studies often raises high quality questions such as, does the checks and balances is a doctrine, principle, or legal theory, or maybe precisely the formula of power in politics. History been recorded, that in any discussions regarding the formation of the constitutional separation, division and smelting power is something that is popular to be discussed before and even after becoming the constitution. Therefore, the casting of checks and balances into the constitution especially on islamic modern society is an interesting study to determine the portion and posture. This study will use Indonesia legal system and its Islamic Society as case study and will be using legal normative methodoloy, on the other hand, comparative studies on constitution which will be conducted and using classic and modern constitutional law literature. Several approach will be use on this research such as, historical, political, economical approach on understanding the practice on checks and balance which pouring in constitutions in some countries.
\end{abstract}

Keywords - Checks and balances, Politics and Constitution, Separation Power

\section{INTRODUCTION}

$\mathrm{O}$ ne of the Parlaiment chamber of in the United States Congress has the power to veto the naturalization policy, even if the candidate is eligible objective to become an American citizen [1]. Constitutional Court in Germany may have an obligation to issue laws that regulate abortions more stringent [2]. In Indonesia, the structure of the chamber in the parliament has a function that is not balanced in the oversight the executive [3]. Does such things were found and give you a series of questions, such as Does an institutional mechanism that kind is acceptable?. It defined as the application of checks and balances? When we start initiate discussions on checks and balances, Lord Acton's word, (1910) "Power tends to corrupt, and absolute power corrupts absolutely" is something that is popular with respect to the underlying [4]. That kind of shaft that later gave birth to the atomic nucleus of the idea of constitutionalism, which is then not only inspire western mindset of management powers then inspire also in eastern mindset regarding the same. [5]. [6][7] and [8] did make a long debate about the factors within the social subsystem that saw actors in the country as the orbit of power. Based on the description, the government with the more concentrated will power tends to corrupt. The only way to eliminate corruption is to give the dispersal of power. Therefore, the constitution must divide power among the various elements of the government so that they can check each other. One solution might eventually need to be found to share power in the state, he built a method of checks and balances in the constitution. For some doctrinal stated that the real constitution has aims to create a balance of power between different parts of government so that they can inspect and supervise each other. Checks and balances are the essence of 
constitutionalism [9]. But the question is checks and balances is a doctrine, principle, or theory in the field of jurisprudence, or precisely the formula of power doctrine in politics. History records that in any talks regarding the formation of the constitutional separation, division and smelting power is something that is popular to be discussed before and even after becoming constitution. Therefore, the casting of checks and balances into the constitution of a study to determine the portion and posture of pouring in.

\section{METHOD}

This research was compiled using normative legal research methods. Legal normative research, conducted by examining library materials or mere secondary data, this type of research is said to be normative legal research in addition to the existence of empirical legal research that examines primary data. This normative legal research includes: (i) research on legal principles, (ii) research on systematic law, (iii) research on vertical and horizontal synchronization legal levels, (iv) legal comparison, and (v) legal history.

\section{RESULT AND DISCUSSION}

\section{Separation of Power in Islamic Society}

Discussion about the checks and balances is still an ambiguous order, considering whether the checks and balances the principles, theories, concepts, or even just the methods in managing and regulating power. For [10] checks and balances correlate closely related to the doctrine of separation of powers. Separation of powers doctrine reflecting the views of John Locke and Baron de Montesquieu, the forerunner of the origin of the constitutional equilibrium theory or theory of balanced Constitutions. The theory is itself a philosophical approach of the concept of mixed government. Checks and Balances has pattern and doctrinal formation is closely related to the formation of separation of powers doctrine which built with with the intention of power inspiring an ongoing. The concept of limitation of the power itself becomes something natural because of all the people, from the smallest to the biggest, weakest to strongest though, from the primitive to the most advanced will always be the possibility of a fundamental difference between the ruler and the ruled. This means that no power is not regulated. [11] tell that every society existing power arrangement, there is a law surounded, as stated by Cicero (106-43 BC) who said "ibi societas ibi ius", where there are people there is a law. In Islam, the ones who ruled as the holder of power, tend to abuse power, especially when the power is gathered in one hand or body. Then, the truth of it is informed in the Qur'an: "Nay! Verily, man does transgress all bounds (in disbelief and evil deed, etc.). Because he considers himself self-sufficient." If people feel themselves sufficiently powerful, military enough, has mass support, quite a treasure, and strong usually plagued with smugness. History has recorded a lot of evidence about the rulers who exceeded the limit for himself as selfsufficiency as an example is the pharaoh who declared himself as a god, as mentioned in the Qur'an that: "and Pharaoh said: "'O chiefs! I know not that you have an ilah (a god) other than me, so kindle for me (a fire), O Haman, to bake (bricks out of) clay, and set up for me a Sarhan (a lofty tower, or palace, etc.) in order that I may look at (or look for) the Ilah (God) of Musa (Moses); and verily, I think that he [Musa (Moses)] is one of the liars." (QS Al Qhashash, /28: 38)

Iniquity exceeded conducted by the Pharaoh to regard him as a god, at a lower level, also conducted by King Lois XIV (1638-1715) who identified himself as state. when he said, "L'Etat c'est moi". Therefore, the power in the state should be limited to be divided or separated or smelted. The separation of powers is often encountered in the state system in many countries, even though the division limitation was not too perfect, sometimes one another is not completely separate, even on interplay situation. The separation of powers doctrine actually teach about the state and law although ultimately explains the formulation of the separation of powers for positioning balanced between the rule of law. It was then taught by [12] and [13] about divide and separate the functions of state power. [13] thought on the separation of powers is due to the principle of 
freedom which is defined by which "a right doing whatever the laws permit, and if a citizen could do what they forbit he would be no longer possed of liberty, Because all his fellow citizen would have the same power", The principle of separation of powers proposed by Montesquieu, indicating the establishment of democratic political life, freedom and independence to actualize all the potentials of individuals and groups can freely do. Therefore any form of rights of each individual and group can be expressed in various forms, hence the need for guidelines to regulate traffic so that the needs and interests of all parties can be met and served. the principle of separation of powers are proposed by Montesquieu is the embodiment of the principle of "rule of law".

In the teachings of Islam's own concept of dispersal of power has occurred when the Prophet Muhammad established the state of Medina. The functions of the executive, legislative, and judicial branches have showed existence in state through the word of Allah Almighty: "Indeed We have sent Our Messengers with clear proofs, and revealed with them the Scripture and the Balance (justice) that mankind may keep up justice. And We brought forth iron wherein is mighty power (in matters of war), as well as many benefits for mankind, that Allah may test who it is that will help Him (His religion), and His Messengers in the unseen. Verily, Allah is All-Strong, All-Mighty." (QS Al Hadiid,/57: 25)

Muhammad Alim give his opinion, that the Prophet Muhammad whose job conveying the laws of Allah SWT symbolizes the executive, All books symbolize legislative, and the balance symbolizes justice. [14] wrote in his explanation of the word of Allah, namely: "Religion will not be straight with strong and victorious, but with tangible and erect three cases, namely: the Book, Balance Sheet, and Iron (or: legislation), (government have legislation), the power of the judiciary and military power to defend the religion. Kitab (laws and regulations), for guidance. Balance, to uphold justice. Iron, to uphold and protect the Book (laws and regulations). " However, the signs of dispersal of power in a state that has not been implemented by the Prophet Muhammad horizontally. It is due to Allah's command, among others: "And We have not sent you (O Muhammad) except as a giver of glad tidings and a warner to all mankind, but most of men know not." (QS Saba, /34: 28). According to Muhammad Alim word of God has clearly provides for the executive to Rasulullah SAW. The words of Allah: "What Allah gave as booty (Fai') to His Messenger (Muhammad) from the people of the townships, - it is for Allah, His Messenger (Muhammad), the kindred (of Messenger Muhammad), the orphans, Al-Masakin (the poor), and the wayfarer, in order that it may not become a fortune used by the rich among you. And whatsoever the Messenger (Muhammad) gives you, take it, and whatsoever he forbids you, abstain (from it), and fear Allah. Verily, Allah is Severe in punishment." (QS Al-Hasyr, /59: 7). On delegation of authority, Muhammad Alim argued that the Prophet Muhammad also acts as a legislator. Then in another verse: "But no, by your Lord, they can have no Faith, until they make you (O Muhammad) judge in all disputes between them, and find in themselves no resistance against your decisions, and accept (them) with full submission." (QS An-Nisaa, /4: 65) Those provisions clearly provide the authority to hear the Prophet, thus functioning as a judiciary. Although the Prophet focused himself against the three functions of power, namely the executive, legislature and judiciary does not mean intends to misuse of power, but to carry out Allah's command. This was disclosed by the following verse: "Indeed in the Messenger of Allah (Muhammad) you have a good example to follow for him who hopes in (the Meeting with) Allah and the Last Day and remembers Allah much." (QS Al Ahzab,/33: 21)

Principle of separation of powers in practical terms, is put into a state principle in the United States, and the debates that took place during the preparation of the United States Constitution is the culmination point of its application Checks and balances into practical norms. Conception which was launched in forming constitution originally desired by the United States to divide the power of the state is considered to provide a checks and balances each other. The first rule that the legislative power, the power to make the law given to Congress; The second rule that the executive power, the power to implement the law, which was given to the President; the third power of 
the judicial authorities, which is given to the Supreme Court. This idea was started by the idea of Federalist supporters of the idea that evolved in the formation of the norm in the United States Constitution. In the debate over drafting the constitution, their expectations of the process of the rule of law and state power that offset each other and watched.

Checks and balances are combined conception of power that wants the three branches of state power to limit each other. Checks are functions to control the power with other powers and functions which is useful to create a balance against other powers. Principles of the doctrine gives the constitutional power to offset the power functions with one another. Mutual monitoring and balancing function integrated in the legislative, executive, and judiciary, which then provides three power offset three other powers that serve to dominate one another.

At the level of the application of the doctrine in the Constitution, the United States has implemented a policy based on the law. In the conception of the separation of powers, the President was given the power to apply for and hold a special session in Congress and some judicial power such as forgiveness. The President also has the power of veto which represents the chief executive to reject a bill that is not approved to become law. But on the other hand, the Congress has the power to balance the power of the veto by a $2 / 3$ voting members of Congress. In addition, the Senate granted executive power and judicial power. In addition, Congress may refuse to grant the proposed state budget for the implementation of the activities of the executive branch nor the other, this shows the power of implementation of the relationship between the branches in the United States grappled with each other to offset each other and watched.

Theories and concepts of separation of powers and checks and balances in the pattern of politics in America today is considered the most solid in both the theoretical building, as well as the level of constitutional convention. Gary Wesserman even praised the conception formed by the American constitution because it was gifted power through constitutional balance the types and other forms of power that no other power is branched. An example is the Congress split into two institutions, and the two institutions must be mutually approve any bill to be discussed before the law applies. Restrictions on the power with the power usage patterns through the method of checks and balances to make every state power are correlated to not be too strong between the power with power. MP's in general, by convention, will be selected for a maximum of two terms; to members of the Senate have a longer tenure of the six years which is actually selected by the state of origin; for president, has a term of four years with a maximum of two periods were selected through elections conducted by the general electorate is not popular elections that usually do before the electoral vote is done. Regarding the judicial authority, Supreme Court justices are appointed by the President after approval by Parliament of the Senate, which was then sworn to independent and free from the influence of other powers in deciding each case.

State power Construction such of it, what result of the division of powers is and mixing separate state agency that in practice divide and disperse the entire power of the state to govern. Most power is used and implemented to run the state government, while others run for offsetting and supervise other powers. But the pattern formed on the basis of the concept of checks and balances is not intended to create a pattern of governance, which in essence is efficient to run, so the logical consequence that the existence of stagnation or often referred to as political "gridlock" [15]. But [16] declare him "to control the abuses of government" and meant that the government can control himself. Even historians like [17] called the checks and balances in the United States as "a harmonious system of mutual frustration".

In France the development of the concept of checks and balances grow along with the concept of separation of powers since the nineteenth century. In medio, there is then argued that in the absence of separation of powers so that's where not freedom. French constitutional system which basically originated from an empire that put the kingdom as sentrum state power today transformed in such a way 
since the end of the 1875 constitution, because the constitution is the last time that France introduced a system of cabinet. Especially since General De Gaulle apply the Fifth Republic Constitution in 1959, then that's when the republican system in which the concept of checks and balances applied by the different designs compare to United States of America [18]. The separation of powers and checks and balances provide a clear objective on which to maintain balance and direction of government which was about to be directed to social purposes. The doctrine of separation of powers and checks and balances is highly dependent on the design of social background [19].

The pattern of third world governments, especially in parts of Asia and Africa have a view directly opposite is actually worried that the checks and balances would cause excessive turbulence, most gridlock, jams, and even civil war [20]. Actually, the design of checks and balances will be very dependent on the desired design. When a system of checks and balances is poorly designed, it does not mean there can lead to disastrous results. But when it was designed, not to cause excessive anxiety then almost all countries that have had a steady political system of checks and balances based on the pattern of its own flavor. Power and the only alternative to de-concentrated concentrated power, which, as has been observed, always eventually leads to the oppressive rule, which is much worse than a political debate. Constitutional design can effectively minimize turbulence and maximize protection against government corruption and arbitrary. There are several different ways to divide power between the branches of state power. For one thing, different constitution making different governmental actors. Some of the constitution gives the president the power of government to others, gives power to the prime minister and several others combine executive and legislative power in Parliament, so some states do not position the form of the kingdom except single government authority granted to the president or prime minister. Some constitutions in some countries recognize the government that is single without having board representation and most other countries do not. Some constitutions make two legislative chambers while other countries apply a single room, and in some countries consists of the legislative chambers. In a different constitutional system will produce different patterns with the order of the corresponding social subsystem that supports the pattern adopted.

In some ways, though the constitution determines the laying of power to a branch of the same powers. Some constitutions in some countries are also able to disperse power to the patterns and formulas are different. In America, for example, according to the constitution the President has the power to veto parliamentary initiative in making the legislation, but in Indonesia the President has no such power, but has the same formulation in strong design. In the UK, the upper house has the power to make recommendations binding to the lower house in the formation of bill, and even has the power to reject the proposed norm of the lower house, while in Indonesia, People Consultative assembly (MPR) has a position to function parallel to House of Representatives (DPR). In terms of vertical power sometimes low governmental power has greater autonomy than the provinces, but sometimes the opposite is true where the provincial governments control more than the lowest and the local government provides even more pressure on the central government.

Constitutional design in the most countries experiences how to divides the powers of the central government into three parts - the legislative, executive, and judicial power. Such constitution gives each of these powers to a different person or group of people. Some of this constitution are trying to divide this power hermetically, ie there should be no overlap between the branches of state. Some provide some overlap, for example, the president has executive power but also legislative veto. This method divides the power of so-called classic separation of powers. In addition, some of the constitution divides power between the central government and regional or provincial governments. Because of this division is the division of constitutional, the central government may not interfere into the sphere of the state. The state government can not dissolve the state government, or maybe it was trying to take for himself one nation 
guaranteed strength. In fact, some states even have their own design of constitution, and they usually have the legislative, judiciary and executive, as the central government. This method is called federalism. Another pattern is when all the legitimate constitution divides power between the government and society to protect the rights of individuals. Some of these rights are personal, such as the right to marry. But some are political, such as the right to protest or to form political associations. By using this right, citizens can check their government. This method of power sharing power on the basis of human rights. Those patterns are all advanced democratic constitution divides power between government and citizens by holding a leadership succession. In a democracy, the people have all the authority and the same political rights; government serving them, not vice versa. But people can not perform activities of government because it is the impossibility of it. Therefore, the constitution gives the power of government officials to carry out their duties, within the scope of that suit them, as representatives of the people.

\section{Indonesia's case}

In terms of the state's leadership in general to know some of the terms of the authority of government, some of which we know the concept King and Queen, Amir (The Ruler), Chairman, President, and Prime Minister. The concepts are sundry usually adjusted to the official language used in the countries concerned. For example, in some muslim major countries, the term King is sometimes called the Sultan as it is practiced in Brunei Darussalam and Malaysia. In the neighborhood communist countries, such as the China, known as the term to refer to the position of Chairman of the Head of State. While in Germany and Austria, the Head of Government called the Chancellor. The term is often used because the executives more flexibility in understanding. [21] [22]it self split into two meanings executive understanding that: (1) Executive in the broad sense, ie the whole body of ministers, civil service, police and even the military. (2) The Executive in the narrow sense, which means the highest leadership of executive power.

The use of the word "executive" means the following
Heads of Government ministers are generally called a cabinet, or in other words, the state agency authorized by the constitution to carry out the laws that have been approved by the legislature submiting the policy. However, in modern practice, the executive who formulate most of the policies and submitted to the legislature for approval. Executive agency is an institution that must exist in any state, especially in the modern state. It is caused by the modern state associated with large national community that requires heads of government who holds wide powers anyway. Some important powers held executive in a constitutional state, among other: (a) Diplomatic power, which is associated with the implementation of foreign relations (b) Administrative power, which is associated with the implementation of the law and public administration; (c) Military power, which is associated with the organization of the armed forces and the conduct of the war; (d) Judiciary, which involves the provision of forgiveness (pardon), reprieve, and so the inmates or criminals; (e) Legislative, which is associated with the drafting of legislation and regulate the enactment into law.

In this world there are three types of government systems and are used in practice, namely (1) presidential system, (2) parliamentary system and (3) mixed system. In the system of government that a presidential system, where the presidency is very important. The definition of the presidential institution is an institution or an organization comprising two office positions, namely the President and Vice President. Some traits that are important in a presidential government system, among others: (1) Chief Executive or the President and/or Vice President has a certain period of time (fixed terms office), eg 4 years, 5 years, 6 years or 7 years. So the President and the Vice President can not be dismissed amid tenure because of political reasons. In some countries, the period of tenure is usually restricted to the firm, for example, only one more term or tenure of only two times in a row; (2) President and Vice President is not accountable to specific political institutions commonly known as a parliament, but directly responsible to the people. President and Vice President shall be removed from office for reasons of unlawful legal conduct that are 
usually restricted to cases of certain criminal acts which if left unchecked can lead to serious legal problems such as treason, inconstitutional conduct and so forth; (3) Therefore, usually the President and/or Vice President is determined directly elected by the people (directly elected) or through certain intermediary mechanisms that do not permanently representation as the nature of parliamentary institutions. In a parliamentary system, a prime minister though also elected through general elections but the election as the Prime Minister not because the people directly, but rather because he was elected a member of parliament who control a majority of seats certain amount; (4) In conjunction with the parliament, President and/or Vice President is not subject to the parliament, can not dissolve parliament, and vice versa Parliament can not impose the President and/or Vice President and dismiss the cabinet as well as in the practice of parliamentary system; (5) In a presidential system, it is not known distinction between the functions of head of state and head of government. While in the parliamentary system, the distinction and separation of the two offices and even heads of state and government of the norm and it is a necessity; (6) The responsibility rests with the government of the President, and therefore the executive branch, in principle, authorized to form a government, a cabinet, appoint and dismiss ministers and public officials that the appointment and dismissal made by political appointment.

In Indonesia there has been a fundamental change in the executive power after the change of the 1945 Constitution is in accordance with the principle of the beginning of the 1945 changes, especially concerning the executive realm, namely to reinforce the presidential system and was followed by the separation of the branches of state power major with the principle of checks and balances, then identifying the fundamental changes in 1945 also resulted in a change in the field of executive power in Indonesia, namely: (1)The President as the holder of executive power [vide Article 4 (1) The 1945 Constitution] no longer holds the power to make laws (laws) that have been shifted into the hands of the House of Representatives [vide Article 20 (1)], it is only entitled to propose draft legislation (bill) to the House of Representatives [vide article 5, paragraph (1)], provides mutual agreement with the Parliament and pass the bill into law [vide article 20 paragraph (2) and (4)]; (2) The President and the Vice President is no longer elected by the Assembly, but elected by the people directly in pairs of candidates nominated by political parties (vide Article 6A); (3) The term of office of the President for 5 (five) years strictly limited to only two periods (see Article 7); (4) it determines the conditions in more detail to be president and vice president (see chapter 6); (5) it determines the mechanism of impeachment against the President and/or Vice President of involving Parliament, the Constitutional Court, and People's Consultative Assembly (vide Article 7A and 7B); (6) The assertion that the president can not dissolve the House of Representatives (vide Article 7C); (7) The exercise of the prerogative of the president as head of state must be with the consent or consideration of the Parliament; (8) Appointment of public officials, a case member of the state's financial examiner body (vide Article 23F), supreme court justice [vide Article 24A paragraph (3)], a member of the judicial commission [vide Article 24B paragraph (3)] need the approval of Parliament; (9) The President is authorized to form the consultative council (vide article 16) as a replacement for Consultative Board to be abolished; (10 In the establishment, alteration, and the dissolution of the ministry should be regulated in the Act [vide Article 17 paragraph (4)], not free as before.

On legislative power is a branch of power that first of all reflect the people's sovereignty. [24] stated that the legislative body that holds the state legislature is a body that reflects one of the agency's functions, namely legislate, or make laws. According to Miriam Budiardjo, another name that is often used is the Assembly that prioritizes elements of "gathering" (to discuss public issues) and other names are Parliement, which is a term that emphasizes the element of "talk" (parler) and negotiate. Another term priority to representation or representation of its members and the so-called People's Representative Body or the House of Representatives. Changes in the system of representation and legislative powers after a 
constitutional reform to bring renewal legislative power in Indonesia, following a system of representative and institutionally legislastive power and its authority. People's Consultative Assembly (MPR) are No longer serves as the highest state institution implementing fully the sovereignty of the people [vide article 1, paragraph (2)]. So, Its membership consists of all members of the DPR and DPD selected through election [vide article 2, paragraph (1)]. The Authority only establish and amend the constitution, inaugurating the President and Vice President [vide Article 3, paragraph (1) and (2)], dismiss the President and Vice President by the constitutional provision [vide article 3, paragraph (3) jo. Article 7A and Article 7B], choose a Vice President from the candidates nominated by the President in case of vacancy Vice President [vide Article 8 paragraph (2)], and elect the President and Vice President if both remains incapacitated simultaneously [vide Article 8 paragraph (3)].

On House of Representatives (DPR), the Members are elected by popular vote [vide Article 19 paragraph (1)]. Holds the power to make laws [vide Article 20 (1)]. Holds legislative function, the function of budget and oversight [vide Article 20A paragraph (1)]. Holds the authority to: propose the dismissal of the President and/or Vice President to the Assembly through the Constitutional Court [vide Article 7 paragraph (1)], to give approval of the Act together with President [vide Article 20 (2)], a declaration of war, make peace and agreement with other countries as appointed by the President (vide article 11), giving approval of nominees to the proposal of the Judicial Commission, the approval of the appointment of a member of the Judicial Commission, giving consideration to the President on the appointment of an ambassador [vide article 13 paragraph (2)], receive placement ambassadors of other countries [ vide article 13 paragraph (3)], and the granting of amnesty and abolition [vide article 14 paragraph (2)]. Choosing a candidate member of the State's Financial Examiner Body [vide Article 23F Paragraph (1)], and proposed three candidates for constitutional judges to the President [vide Article 24C paragraph (3)].

On Regional Representatives Council (DPD), the members represent each province were selected through an election [vide Article 22C paragraph (1)] and all its members automatically are members of the Assembly [vide article 2, paragraph (1)], the number of members of each of the same province and keseluuruhan must not be more than one third of members DPR [vide article 22 paragraph (2)]. Holds authority to: propose to Parliament [vide Article 22D paragraph (1)] and participate in the discussion [vide Article 22D paragraph (2)] bill relating to regional autonomy, the central and local relations, formation and sensitization as well as the merging of regions, resource management natural and other economic resources, as well as related to the financial balance between the center and the regions, giving consideration to the Parliament on Budget bill and the bill relating to taxes, education and religion [vide article 22D paragraph (2)], as well as the election of members of the State Financial Examiner Body [vide article 23F paragraph (1)], and supervise over the implementation of the law on regional autonomy, the formation, expansion and merger of regions, central and local relations, management of natural resources and other economic resources, the implementation of the state budget, tax, education, and religion [vide section $22 \mathrm{D}$ paragraph (3)].

Thus, according to the representative system and the legislative authority has been very significant changes occur as follows: (i) No longer is the supremacy of the assembly, but the tendency of the theory espoused trias politica with the principle of checks and balances system; (ii) to shift from a unicameral system to semi-bicamereal with DPD despite a very limited role, and the loss of functional representation system with the abolition of group representatives in the Assembly; (iii) Shifting power to make laws from the President to the Parliament. Associated with a branch of judiciary, the Indonesian constitution laid the judicial power as a third pillar in the system of state power more modern Indonesia. In the modern state system, judicial branches of power according to the power branch is organized separately. John Alder and Peter English (1989) states, "The principle of separation o powers is particularly important for the judiciary." Even Montesquieu was a judge in France, so he wants the importance of the separation of powers is extreme 
among the branches of the legislative, executive, and especially the judiciary. [23]

There are two very basic principles that are considered in the judiciary, namely (i) the principle of judicial Independence, and (ii) the principle of Impartialy. Both of these principles are recognized as a fundamental prerequisite system in all modern constitutional state or a modern constitutional state. Principles of Independence itself, among others is to be realized in the attitude of the judges in examining and deciding cases that it faces. In addition, independence is also reflected in the various arrangements on matters relating to the appointment, employment, career planning, payroll, and dismissal of judges. In the Indonesian context, there is a period of history that shows that law enforcement judicial power can not be qualified as an Independent. Indications on it can be argued from a variety of the following, namely: (1) In the era of colonialism, the judge in Hoogerechtsthof and Raad van Justitie is separate from government employees, while the chairman Landraad in Java and Madura and disebagian outside Java and Madura are government employees who usually arriving under the Ministry of Justice; (2) At the time of the old order, the judiciary is placed as a legal revolution to meet the demands for social justice, article 19 the 1964 Principles of Judicial Power Law, stated "For the sake of the revolution, the honor of the State and Nation can participate or intervene about--hand in the matter of the court". So is the case with the authorities of other law enforcement agencies; (3) In the old order era, the President put the Chief Justice as a Cabinet Minister with three (3) positions, namely: Minister of Presidential Legal Adviser, Ministry of Justice, and also served as Chairman of the Supreme Court. (4) In the New Order, the President no longer placing the chief justice under the rule of President but the terms of a judge to be appointed and dismissed have stipulated by Act and in the legislation referred to no authority of the President to determinening the judge. Post reformation constitution on 1999-2002, there is a fundamental change, especially the birth of the Constitutional Court and the Judicial Commission. So that the field of Judiciary system have regulated matters as follows: (1) The assertion of the independence of the judicial power in the articles of the 1945 Constitution [vide paragraph 24 (1)], whereas previously only in the explanation (as a consequence of the abolition of the explanation of the 1945 Constitution); (2) Judiciary power is no longer a monopoly of the Supreme Court and judicial bodies who are below, but also by the Constitutional Court [vide Article 24 paragraph (2) Constitution NRI 1945]; (3) The existence of an independent Judicial Commission, which is authorized to propose the appointment of justices and have other authorities in order to maintain the dignity and behavior of judges (see article 24B); (3) The presence of the Constitutional Court with nine (9) constitutional judges (three of the Parliament's suggestions, three proposals MA, and three of the President's proposal) that has 4 (four) authority and one (1) obligation (vide Article 24C): (a)Reviewing laws against the Constitution; (b) Determining disputes over the authorities of state institutions whosepowers are given by this constitution; (c) Deciding over the dissolution of political party; (d) Deciding over disputes on the results of a general election; (e) Authority to issue a decision over a petition concerning alleged violation by the President and/or the Vice President as provided by the constitution.

\section{CONCLUSION}

As illustrated in the last part, there are many ways to divide power. Some constitutions use different types of division; others only a few uses. There is no single correct way to share power for all countries at all times. Instead, the crucial point for the purpose of this is that the different ways of sharing power have different effects. Because of checks and balances is the heart of constitutionalism constitutionalist has devoted a long time to research, the focus of research on the effects of different ways to divide power, both alone and in combination. But there is no constitutional system does everything well; there is always a trade-off, or the choice to be made. Some of the constitutional system are made, for example, tends to cause very inclusive but rather has a pattern of offending politically; others will lead to a little more exclusive, but also more stable in the political 
system. Some systems give rise to constitutional politics focuses on ideology but not local interests; others have focused on the interests of local politics but not ideologies, and so on. All the systems have advantages and disadvantages as well.

On the basis as described then, a different system will work better for different countries. For example, some countries have a cultural tendency to centralize the power of just one person, to the executive, who then try to collect all of the rest of the power for himself. For those countries, it is very important to weaken the executive to give more power to the legislative and judicial branches. Perhaps there is a downside: a country with a weak executive sometimes can not respond quickly to changing world events. But on balance, for the kind of country, inverse avoid tyranny exceeds downside slower reaction time. Constitutional design as an art of norm consists of adjusting the constitution of certain countries in this way

\section{REFERENCES}

[1] P. Gerangelos, The Separation of Power and Legislative Interference in Judicial Process: Constuttional Pronciples and Limitations, New York: Hart Publishing, 2009.

[2] C. Mouffe, The Democratic Paradox, Newyork: Verso, 2000.

[3] D. Indrayana, "Indonesian Constitutional Reform 1999-2002: An Evaluation of Constitution -Making in Transition [Disertation]," Faculty of Law, University of Melbourne, Melbourne, 2005.

[4] J. E. E. Dalberg and L. Acton, Lectures of the French Revolution, Indianapolis: Liberty fund, 1910.

[5] C. J. Friedrich, Constitutional Goverment and Democracy, Havard: Blaisdell Publishing, 1968.

[6] C. H. Mellwain, Constitutionalism: Ancient and Modern, London : Cambridge Universiity Press, 1939.
[7] T. R. S. Allan, "Dworkin and Dicey: The Rule of Law as Integrity," Journal of Legal Study, 1988.

[8] A. Heywond, Political Ideologis, Oxford : Mcmillian Publishing, 1978.

[9] N. Krisch, Beyond Constitutionalism, Oxford : Oxford University Press, 1998.

[10] C. J. Ville, Constitutionalism and Separation of Powers, Indianapolis : Liberty Funds, 1989.

[11] M. Duverger, Teori dan Praktek Tata Negara, Jakarta: PT Pusaka Rakyat, 1961.

[12] J. Locke, Two Treatise on Civil Goverment, Cambridge UK: Cambridge University Press, 1998.

[13] C. d. Secondat and B. d. Montesquiev, The Spirit of Law, Canada : Batoche Books, 2001.

[14] T. M. H. A. Shiddieqy, Pedoman Shalat, Semarang: Pustaka Rizki Putra, 1999.

[15] C. Becker, The Declaration of Independence, Ithaca: Cornell University, 1999.

[16] G. Wasserman, The Basics of American Politics, Pearson: Longman, 2007.

[17] R. Hoftstadter, The American Political Tradition, Ithaca: Cornell University, 1948.

[18] A. d. Tocqueville, Democracy in America: Historical-Critical Edition of De la de'mocratie an Amerique, Indianapolis: Liberty Funds, 1989.

[19] H. Finner, The Theory and The Practice of Modern Goverment, New York, L.MacVeagh: The Dial Press, 1932.

[20] P. Costa, The Rule of Law: History, Theory, and Criticism, New York: Springer, 2006.

[21] J. Asshiddiqie, Pengantar Ilmu Hukum Tata Negara Jilid II, Jakarta: Sekertariat Jendral dan Kepaniteraan Mahkamah Konstitusi Republik Indonesia, 2006.

[22] C. F. Strong, Konstitusi-Konstitusi Politik Modern: Kajian Tentang Sejarah \& BentukBentuk Konstitusi Dunia, Jakarta: Nusamedia, 2004.

[23] A. M. Fadjar, Hukum Konstitusi \& Mahkamah Konstitusi, Yogyakarta: Citra Media, 2006.

[24] M. Budiarjo, Dasar - Dasar Ilmu Politik, Jakarta : PT. Gramedia Pustaka Utama, 2008. 